\title{
GAMBARAN PERSEPSI IBU HAMIL TENTANG MITOS KEHAMILAN
}

\section{Description of Expextant Mothers Perception About Myths of Pregnancy}

\author{
Tri Suhandoyo ${ }^{1}$, Dwi Susanti ${ }^{2}$ \\ ${ }^{1}$ Departemen Keperawatan, Universitas Jenderal Achmad Yani Yogyakarta \\ ${ }^{2}$ Departemen Keperawatan Maternitas, Universitas Jenderal Achmad Yani \\ Korespondensi: soesanti_2@yahoo.com
}

\begin{abstract}
ABSTRAK
Kehidupan sosial budaya akan mempengaruhi persepsi ibu hamil yang seringkali lebih dominan membawa danpak negatif terhadap kesehatan reproduksi ibu dan kesehatan anak. Berbagai mitos kehamilan pada akhirnya menyebabkan ibu hamil kekurangan gizi seperti anemia dan kurang energi kronis (KEK) sehingga rentan terjadi perdarahan dan Berat bayi lahir rendah (BBLR). Peneliti ingin mengetahui gambaran persepsi ibu hamil terhadap mitos kehamilan di wilayah kerja puskesmas Dlingo II Bantul Yogyakarta. Penelitian ini berjenis deskriptif non analitik dengan rancangan cross-sectional. Jumlah sampel yang diperoleh sebanyak 68 responden dengan teknik sampling yang digunakan adalah total sampling. Analisis dalam penelitian ini adalah analisis univariat. Hasil dalam penelitian ini adalah responden memiliki persepsi positif terhadap mitos kehamilan yaitu sebanyak 37 orang $(54,4 \%)$ dan responden yang memiliki persepsi negatif sebanyak 31 responden $(45,6 \%)$. Ibu hamil di wilayah kerja puskesmas Dlingo II Bantul Yogyakarta memiliki persepsi positif terhadap mitos, artinya responden percaya terhadap mitos kehamilan yang berada di masyarakat. .
\end{abstract}

Kata Kunci: persepsi, mitos kehamilan, ibu hamil

\begin{abstract}
Socio-cultural life will affect the perception of expectant mothers which are often more dominantly have a negative impact on maternal reproductive an child health. Various myths of pregnancy ultimately leading to maternal nutritional deficiencies such as anemia and chronic energy malnutrition, so vulnerable bleeding and low birth weight. The aim is to know the description of expectant mothers perception about myths of pregnancy in work area of public health Dlingo Bantul Yogyakarta. The research was kind of non-analytical descriptive with cross-sectioanl design. Number of sample obtained as many 68 resposndents, with total sampling technique. Analysis in this research was univariat analysis. The result of this research was respondent who had positive perception abaout myths of pregnancy as many 37 respondent $(54,4 \%)$, and respondents who had negative perception as many 31 respondent (45,6\%). Expectant mothers in work area of public helath Dlingo II Bantul Yogyakarta had positive perception about myths, it means respondents believe in the myth of pregnancy in the community.
\end{abstract}

Keywords: perception, myth of pregnancy, expectant mothers 


\section{PENDAHULUAN}

Target Angka Kematian Ibu (AKI) di Indonesia pada tahun 2015 adalah 102 kematian per 100.000 kelahiran hidup. Sementara itu berdasarkan Survei Demografi dan Kesehatan Indonesia (SDKI) tahun 2012, Angka Kematian Ibu (AKI) (yang berkaitan dengan kehamilan, persalinan, dan nifas) sebesar 359 per 100.000 kelahiran hidup. Salah satu cara untuk menurunkan AKI di Indonesia adalah dengan persalinan ditolong oleh tenaga kesehatan yang terlatih dan melakukan persalinan di fasilitas pelayanan kesehatan. Berdasarkan data Profil Kesehatan Indonesia tahun 2013 cakupan pertolongan persalinan oleh tenaga kesehatan secara nasional pada tahun 2013 adalah sebesar 90,88\%. Cakupan ini terus menerus meningkat dari tahun ke tahun (Kemenkes RI, 2014).

Kondisi sosial budaya pada masingmasing daerah turut memberikan konstribusi, masih banyak daerah yang masih menggunakan dukun sebagai penolong persalinan, khususnya di desadesa. Penolong saat persalinan dengan kualifikasi tertinggi dilakukan oleh bidan $(68,6 \%)$, kemudian oleh dokter $(18,5 \%)$, dan untuk non tenaga kesehatan $(11,8 \%)$. Namun sebanyak $0,8 \%$ kelahiran dilakukan tanpa ada penolong, dan hanya $0,3 \%$ kelahiran saja yang ditolong oleh perawat (Kemenkes RI, 2014).

Mitos yang terjadi dimasyarakat tidak sepenuhnya berjalan dengan ilmu pengetahuan yang telah berkembang, bahkan masih banyak mitos tentang kehamilan yang membahayakan keselamatan ibu dan janin. Mitos adalah pendapat atau anggapan dalam sebuah kebudayaan yang dianggap mempunyai kebenaran yang isinya tentang anjuran maupun larangan mengenai kehamilan yang pernah berlaku pada suatu masa dahulu hingga sekarang tentunya banyak beredar di masing-masing daerah dan belum tentu kebenarannya (Nirwana, A.B, 2011).

Persepsi terhadap mitos kehamilan baik masalah kematian maupun kesakitan pada ibu sesungguhnya tidak terlepas dari faktor-faktor sosial budaya dan lingkungan dalam masyarakat dimana mereka berada. Disadari atau tidak, faktor-faktor kepercayaan dan pengetahuan budaya seperti konsepsi-konsepsi mengenai berbagai pantangan, hubungan sebab-akibat antara makanan dan kondisi sehat-sakit, kebiasaan dan ketidaktahuan, seringkali membawa dampak baik positif maupun negatif terhadap kesehatan reproduksi ibu dan kesehatan anak. Hal ini terlihat bahwa setiap daerah mempunyai pola makan tertentu, termasuk pola makan ibu hamil yang disertai dengan kepercayaan akan pantangan, tabu, dan anjuran terhadap beberapa makanan tertentu (Nirwana, a.B, 2011).

Budaya pantang pada ibu hamil sebenarnya justru merugikan kesehatan ibu hamil dan janin yang dikandungnya. Misalnya ibu hamil dilarang makan telur dan daging, padahal telur dan daging justru sangat diperlukan untuk pemenuhan kebutuhan gizi ibu hamil dan janin. Berbagai pantangan tersebut akhirnya menyebabkan ibu hamil kekurangan gizi seperti anemia dan kurang energi kronis (KEK). Dampaknya, ibu mengalami pendarahan pada saat persalinan dan bayi yang dilahirkan memiliki berat badan rendah (BBLR) yaitu bayi lahir dengan berat kurang dari $2.5 \mathrm{~kg}$ (Manuaba, 2010). Berdasarkan permasalahan tersebut peneliti tertarik untuk melakukan penelitian dengan judul "Gambaran Persepsi Ibu Hamil Terhadap Mitos Kehamilan di Wilayah Kerja Puskesmas Dlingo II Bnatul Yogyakarta”.

\section{TUJUAN PENELITIAN}

Peneliti ingin mengetahui gambaran persepsi ibu hamil terhadap mitos kehamilan di wilayah kerja puskesmas Dlingo II Bantul Yogyakarta.

\section{METODE PENELITIAN}

Desain

Penelitian ini merupakan penelitian deskriptif non analitik dengan metode penelitian adalah studi korelasi (correlation study). Rancangan penelitian ini menggunakan cross sectional (Notoadmojo, 2012). Tujuan penelitian ini adalah untuk mengetahui gambaran persepsi ibu hamil tentang mitos kehamilan.

\section{Populasi dan Sampel}

Populasi dalam penelitian ini adalah ibu hamil di wilayah kerja Puskesmas Dlingo II Bantul Yogyakarta dengan jumlah sampel sebanyak 68 ibu hamil. Teknik sampling yang digunakan adalah total sampling (Notoadmojo, 2012).

\section{Tempat dan Waktu Penelitian}


Penelitian ini dilaksanakan di wilayah kerja Puskesmas Dlingo II Bantul Yogyakarta pada bulan Agustus 2017.

\section{Instrumen dan Prosedur Pengukuran}

Pada penelitian ini pengumpulan data dilakukan dengan menggunakan kuesioner persepsi ibu hamil tentang mitos kehamilan. Kuesioner ini terdiri atas 40 pertanyaan, yang terbagi dari pertanyaan pantangan makan, pantangan perbuatan, sesepuh atau pepunden dan acara selametan kueisioner ini disusun menggunakan skala likert (Nursalam, 2013). Kategori jawaban dari pertanyaan-pertanyaan yang disusun dijabarkan dalam 2 bentuk yaitu positif (mendukung) dan negatif (tidak mendukung). Setiap jawaban akan diskor dan pemberian skor berdasarkan pada jawaban positif dan negatifnya suatu pertanyaan. Untuk pertanyaan-pertanyaan yang positif skor tertinggi terletak pada sangat setuju (SS) dengan skor 4 dan skor terendah pada sangat tidak setuju (STS) dengan skor 1. Sebaliknya untuk butir-butir pertanyaan yang negative skor tergtinggi terletak pada jawaban sangattidak setuju (STS) dengan skor 4, dan skor terendah pada jawaban sangat setuju (ST) dengan skor 1 (Khoililurrohman, 2003).

\section{Analisa Data}

Analisa univariat dilakukan pada data karakteristik responden.

\section{HASIL PENELITIAN} ini:

Hasil akan disajikan dalam tabel berikut

Tabel 1

Karakteristik Ibu Hamil di Wilayah Kerja Puskesmas Dlingo II Bantul Yogyakarta $(\mathrm{n}=68)$

\begin{tabular}{lcc}
\hline Karakteristik & $\mathrm{n}$ & $\%$ \\
\hline Usia Ibu & & \\
17-25 tahun & 32 & 47,1 \\
26-32 tahun & 18 & 26,5 \\
33-40 tahun & 18 & 26,5 \\
\hline Usia Kehamilan & & \\
$\quad$ Trimester I & 8 & 11,8 \\
Trimester II & 23 & 33,8 \\
$\quad$ Trimester III & 37 & 54,4 \\
\hline Agama & & \\
Kristen & 6 & 8,8 \\
Islam & 62 & 91,2 \\
\hline Pendidikan & & \\
SD & 9 & 13,2 \\
SMP & 20 & 29,4
\end{tabular}

\begin{tabular}{lcc}
\hline Karakteristik & $\mathrm{n}$ & $\%$ \\
\hline SMA & 28 & 41,2 \\
PT & 11 & 16,2 \\
\hline Suku & & \\
Jawa & 68 & 100,0 \\
\hline Pekerjaan & & \\
PNS & 2 & 2,9 \\
Wirawasta & 5 & 7,4 \\
Pedagang & 7 & 10,3 \\
Swasta & 8 & 11,8 \\
\hline IRT & 46 & 67,6 \\
\hline Pengahasilan & & \\
$\quad<1.200 .000$ & 61 & 89,7 \\
$\quad>1.200 .000$ & 7 & 10,3 \\
\hline Kehamilan & & \\
Anak Pertama & 32 & 47,1 \\
Anak Kedua & 27 & 39,7 \\
>Anak kedua & 9 & 13,2 \\
$\quad$ Total & 68 & $100 \%$ \\
\hline$\quad$
\end{tabular}

Berdasarkan tabel 1 usia ibu hamil paling banyak adalah dalam rentang 17-25 tahun yaitu 32 responden $(47,1 \%)$, usia kehamilan paling banyak dalam trimester III yaitu 37 responden (54,4\%). Untuk agama yang dianut ibu hamil paling banyak adalah Islam yaitu 62 responden $(91,2 \%)$, sedangkan untuk pendidikan paling banyak adalah SMA yaitu 28 responden $(41,2 \%)$. Pekerjaan yang paling banyak pada ibu hamil adalah swasta dengan penghasilan paling banyak kurang dari Rp. 1.200.000 yaitu $61(89,7 \%)$. Berdasarkan kehamilan paling banyak adalah kehamilan anak pertama yaitu 32 responden $(47,1 \%)$.

Tabel 2

Persepsi Ibu Hamil Tentang Mitos Kehamilan di Wilayah Kerja Puskesmas Dlingo II Bantul Yogyakarta

\begin{tabular}{lcc}
\hline Variabel & $\mathrm{n}$ & $\%$ \\
\hline Positif & 37 & 54,4 \\
Negatif & 31 & 45,6 \\
\hline \multicolumn{1}{c}{ Total } & 68 & 100 \\
\hline
\end{tabular}

Berdasarkan tabel 2 menunjukkan ibu hamil yang mempunyai mitos positif sebanyak 37 respponden $(54,4 \%)$ dan ibu hamil yang memiliki mitos negatif adalah sebanyak 31 responden $(45,6)$. 


\section{PEMBAHASAN}

Karakteristik Responden

Usia erat kaitannya dengan daya tangkap dan kematangan pola pikir individu. Seiring dengan bertambahnya usia maka daya tangkap dan kematangan pola pikir akan semakin baik (Walgito, B, 2015). Sehingga dengan usia yang matang, diharapkan responden memiliki persepsi yang sesuai dengan realita atau sejalan dengan ilmu pengetahuan.

Seiring dengan bertambahnya usia kehamilan, maka timbul perubahan-perubahan pada ibu hamil. Selain perubahan fisik, terdapat pula perubahan psikologis. Perubahan yang terjadi pada setiap trimester pun berbeda-beda. Pada trimester I, emosi menjadi labil sehingga sangat sensitif, mudah menangis, dan khawatir terjadi keguguran. Pada trimester II, emosi kembali stabil dan mampu beradaptasi dengan perubahan fisik maupun psikologis. Sedangkan pada trimester III, emosi kembali labil serta masalah utam muncul yaitu kecemasan dalam menyambut kelahiran bayi (Harnindita, 2015).

Agama Islam selalu mengedepankan rasionalisme. Islam memandang bahwa benda apapun tidak dapat memberikan manfaat dan mudharat kecuali dengan izin Allah SWT dan tidak akan terjadi sesuatu kecuali atas sepengetahuan dan izinnya (Fitria, 2009). Sehingga apabila responden memegang teguh pada ajaran islam maka segala tindakan ataupun persepsi akan sejalan dengan ilmu pegetahuan atau bisa dibuktikan secara nyata.

Pendidikan erat kaitannnya dengan tingkat pengetahuan. Pendidikan merupakan subuah usaha dalam mengembangkan kepribadian dan kemampuan di dalam maupun luar sekolah. Pendidikan dapat diperoleh secara formal dan informal (Wahyudi, HK, 2010). Semakin tinggi tingkat pendidikan maka diharapkan individu memiliki pengetahuan yang luas dan pemahaman baik.

Setiap daerah memiliki adat istiadat yang berbeda dalam menghadapi atau mengatur ibu yang sedang hamil. Kehamilan dan melahirkan dianggap sebagai fase krisis yang harus dijalani. Fase ini dianggap sebagai fase yang berbahaya bahakan dapat mengancam nyawa sehingga perlu dilakukan upacara adat atau memberikan pantangan supaya bayi dan ibu mendapat keselamatan. Suku jawa merupakan salah satu suku kaya akan adat istiadat dalam memperlakukan ibu yang sedang hamil. Secara tidak langsung apabila individu hidup dalam lingkungan yang memiliki nilai dan norma adat istiadat yang tinggi maka semakin besar pula pengaruhnya terhadap pembentukan perilaku individu tersebut. Individu akan menjadi lebih patuh terhadap norma dan kepercayaan daerah setempat (Meutia. F dan Swasno, 1998).

Status pekerjaan kurang bisa menggambarkan persepsi ibu dalam menyikapi mitos kehamilan. Hal tersebut dikarenakan banyak ibu yang memiliki pendidikan tinggi akan tetapi lebih memilih menjadi ibu rumah tangga. Dengan kata lain, status pekerjaan tidak bisa menggambarkan tingkat pengetahuan ibu hamil.

Keluarga dengan kondisi ekonomi baik akan mudah memenuhi segala kebutuhan hidup baik kebutuhan primer ataupun tersier (Walgito, B, 2010). Kebutuhan informasi dan pendidikan, kebutuhan akan pelayanan kesehatan yang sesuai akan lebih mudah didapatkan apabila individu memiliki penghasilan baik jika dibandingkan dengan individu yang berpenghasilan kurang. Sehingga semakin baik kondisi ekonomi diharapkan individu lebih memilih pelayanan kesehatan yang lebih nyata dan dapat dipertanggung jawabkan kebenarannya.

Kecemasan yang tinggi disebabkan karena ibu primigravida belum pernah mengalami kondisi ini sebelumnya. Emosi yang labil dan mudah dipengaruhi oleh orang lain ataupun lingkungan sekitar menjadi ciri khas bagi individu yang cemas. Jika kondisi tersebut berlanjut, maka individu secara tidak langsung akan mencari mekanisme pertahanan atau koping. Apabila koping individu tersebut maladaptif, maka individu tersebut cenderung akan menimbulkan persepsi yang salah bagi individu, misalnya dengan mempercai mitos kehamilan (Harnindita, 2015).

OA pada lutut merupakan salah satu penyebab utama disabilitas pada lansia (Ma, Chan, \& Carruthers, 2014). Jenis kelamin dan usia dijelaskan merupakan faktor prediktor terjadinya OA. Responden dalam penelitian ini sebagaian besar memiliki jenis kelamin perempuan. Hal ini sesuai dengan teori yang dikemukakan oleh White et al., (2013) yang menjelaskan bahwa OA lebih banyak terjadi pada wanita (White et al., 2013). Cho et al., mengidentifikasi jenis kelamin wanita menjadi faktor predisposisi utama OA pada lutut dan memiliki manifestasi klinis yang lebih buruk dibandingkan dengan laki-laki (Cho, Chang, Yoo, Kim, \& Kim, 2010). Perbedaan hormon antara perempuan dan laki-laki dapat menjadi 
penyebab utama berkembangnya OA., terutama pada wanita postmenopause yang dikaitkan dengan penurunan estrogen (Hame \& Alexander, 2013). Sejalan dengan Hame \& Alexander, penelitian yang dilakukan Richmond et al., mengidentifikasi implikasi potensial yang terjadi reseptor estrogen pada kartilage persendian (Richmond et al., 2000).

Karakteristik responden yang dapat menjadi faktor predisposisi terjadinya OA adalah usia. Usia responden pada penelitian ini memiliki rata-rata usia 65 tahun. Usia yang semakin bertambah mempengaruhi kemampuan sel dan jaringan dalam mempertahankan homoeostasis terutama saat stress (Anderson \& Loeser, 2010). Proses penuaan dan perubahan patologis pada sendi OA pada tingkat molekuler terjadi akibat perubahan intrinsik dalam struktur protein matriks ekstraseluler seperti kolagen dan proteoglikan. Pengerasan pada jaringan kolagen atau peningkatan glikasi dapat menstimulus terjadin glikasi dapat menstimulus terjadinya gangguan fungsi kartilago dan fungsional sendi (Verzijl et al., 2002). Penuaan memiliki peranan dalam peningkatan terjadinya apoptosis dan regenerasi sel.

Pada penelitian ini diketahui nilai nyeri sebelum melakukan latihan tai chi memiliki rata-rata 5,20. Nyeri yang dirasakan responden sebelum melakukan latihan tai chi pada OA lutut sebagian besar memiliki karakteristik nyeri sedang yang intermiten. Penelitian yang dilakukan Hawker et al., (2008) menjelaskan bahwa individu dengan OA lutut dan hip memiliki karakteristik nyeri yang intermeten dan intens (Neologi, 2013). Rasa sakit yang intermiten dan intens dirasakan penderita OA memiliki efek negatif pada suasana hati, menyebabkan gangguan tidur, dan mengakibatkan tidak dapat berpartisipasi dalam kegiatan sosial (Neologi, 2013).

Upaya dalam mengurangi nyeri responden dalam penelitian ini dilatih utuk melakukan latihan psikofisiologikal berupa tai chi. Setelah melakukan latihan tai chi selama 45 menit setiap 2 kali seminggu dalam 6 minggu, nyeri dirasakan semakin menurun oleh responden dibandingkan dengan sebelum rutin melakukan latihan tai chi. Hal ini sejalan dengan penelitian yang dilakukan oleh Shen et al., (2008) yang menunjukan perubahan nyeri yang dirasakan semakin berkurang setelah melakukan latihan tai chi setiap minggu 2 kali selama 6 minggu. Rata-rata skala nyeri setelah melakukan tai chi menurun menjadi 3,83. Dengan nilai rata-rata nyeri selisih antara pretest dan post-test adalah 1,67. (R. S. Richmond et al., 2000).

Tai chi merupakan salah satu latihan yang direkomendasikan dilakukan pada pasien OA pada lutut (J. Richmond et al., 2010). Nyeri yang dirasakan pada OA lutut dapat dikurangi dengan melakukan modifikasi pengobatan melalui latihan tanpa melihat stadium penyakit atau tingkat keparahan gejala OA (Fransen et al., 2015). Pada penelitian ini tai chi dilakasanakan selama 6 minggu. Secara teori, tai chi akan lebih efekif jika dilakukan dalam jangka panjang, namun beberapa penelitian menemukan efek positif dalam menghilangkan nyeri pada OA setelah durasi latihan 6-12 minggu (Brismée et al., 2007). Tai chi merupakan latihan yang menggabungkan teknik pernafasan diafragma dan relaksasi dengan berbagai gaya gerakan secara perlahan dan lembut, dari satu gerakan ke gerakan lainnya dengan gerakan melingkar (Ye et al., 2014). Chen \& Snyder (1999) menjelaskan, tai chi berfokus pada kombinasi dari imajinasi dan kenyataan, ketenangan dan tindakan, serta mencari ketenteraman dalam setiap gerakan (Ye et al., 2014). Tai chi yang dilakukan dan dipraktikkan oleh orang dewasa dengan OA mampu memberikan motivasi dan meningkatkan gaya hidup sehat (Chang, Chen, Lee, Lin, \& Lai, 2016). Selain itu, kekuatan otot ekstremitas bawah serta keseimbangan dan kemampuan koordinasi pasien dengan OA lutut dapat ditingkatkan melalui latihan tai chi (Wang et al., 2009).

\section{Persepsi Ibu tentang Mitos Kehamilan}

Sebagian besar ibu hamil di Wilayah Kerja Puskesmas Dusun Dlingo II Bantul Yogyakarta memiliki persepsi positif terhadap mitos kehamilan yaitu sebanyak 37 orang $(54,4 \%)$, artinya individu tersebut memiliki pandangan setuju akan adanya mitos kehamilan di masyarakat dan lebih mempercayai perkembangan ilmu pengetahuan.

Persepsi merupakan sebuah proses penginderaan yang terjadi akibat adanya stimulasi yang kemudian diorganisasikan dan diinterpretasikan sehingga individu mampu mengenal atau menilai suatu hubungan menurut pandangannya sendiri (Walgito, 2010). Sedangkan mitos kehamilan adalah sesuatu 
yang dianggap memiliki kebenaran dari sisi budaya yang berisi tentang anjuran maupun larangan mengenai kehamilan. Mitos didasarkan pada pengalaman masa lalu yang terjadi di masing-masing daerah, sehingga akan berbeda pada setiap daerah (Nirwana, 2011). Hal tersebut yang menyebabkan mitos tidak sejalan dengan ilmu pengetahuan yang bersifat pasti dan dapat dipertanggungjawabkan kebenarannya. Banyak mitos terutama yang berkaitan dengan kehamilan dan melahirkan terbukti kurang efektif dan tidak sesuai dengan kemajuan ilmu kedokteran dan teknologi.

Adat-istiadat dan budaya memiliki peran yang besar dalam pembentukan persepsi dan sikap bagi penganutnya. Individu yang terlalu berpegang teguh akan sulit menerima hal baru meskipun hal-hal yang dianut tidak sesuai dengan logika atau kemajuan IPTEK. Hal-hal baru yang bertentangan dengan budaya dan adat istiadat mungkin saja akan langsung ditolak meskipun ada teori yang sudah bisa dipertanggung jawabkan kebenarannya. Misalnya saja terdapat beberapa mitos kehamilan, yang dalam penelitian ini terbagi atas 4 bagian yaitu panatangan makanan, panatangan perbuatan, sesepuh dan upacara.

Terdapat 31 orang $(4, \%)$ yang memiliki persepsi negatif. Artinya minoritas responden tidak mempercayai mitos yang ada di masyarakat meskipun banyak yang tidak sesuai dengan kemajuan ilmu pengetahuan dan teknologi. Salah satu mitos yang termasuk upacara adalah ibu hamil perlu mengadakan selametan kecil pada hari neptu. Mengadakan acara untuk keselamatan ibu dan bayi merupakan sesuatu yang boleh dilakukan. Kegiatan yang boleh dilakukan bukan berarti harus atau wajib dilakukan, karena yang terpenting adalah esensi dari kegiatan tersebut yaitu berdoa kepada Tuhan agar diberikan keselamatan. Berdoa dengan banyak orang ataupun berdoa sendiri memiliki makna yang sama di hadapan Tuhan. Hal tersebut disebutkan dalam Al-Qur'an Surah Al-Mulk Ayat 13, Allah SWT berfirman "Dan rahasiakanlah perkataanmu atau nyatakanlah. Sungguh, Dia Maha Mengetahui segala isi hati”.

Jadi, persepsi merupakan suatu pandangan yang dipercayai individu. Persepsi dapat dipengaruhi oleh tingkat pengetahuan seseorang. Apabila tingkat pengetahuannya baik, maka persepsi akan cenderung sesuai dengan logika. Selain tingkat pengetahuan, persepsi juga dipengaruhi oleh nilai adatistiadat dan budaya. Apabila individu memiliki pengetahuan yang cukup akan tetapi bertentangan dengan budaya yang dimiliki maka individu akan lebih cenderung mengabaikan pengetahuan dan lebih memilih budaya yang ada. Sehingga dapat dikatakan, dengan merubah persepsi bukan berarti sikap atau perilaku individu akan berubah.

\section{KESIMPULAN \\ Implikasi}

Sebagian besar responden memiliki persepsi positif terhadap mitos kehamilan, sehingga untuk mengurangi terjadinya respon negative maka profesi keperawatan dapat lebih meningkatkan promosi kesehatan, khususnya tentang pemberian asuhan keperawatan yang tepat bagi ibu hamil. Penggunaan media promosi dibuat semenarik mungkin dan menyeluruh di setiap daerah sehingga tidak ada daerah yang ketinggalan informasi.

\section{Keterbatasan}

Penelitian ini merupakan penelitian dengan satu variabel, untuk itu perlu dilakukan penelitian lebih lanjut untuk mengetahui lebih spesifik tentang mitos-mitos dalam kehamilan.

\section{DAFTAR PUSTAKA}

Fitria. 2009. Prinsip Dasar dan aplikasi penulisan laporan pendahuuan dan strategi pelaksanaan tindakan. Jakarta: salemba medika.

Harnindita. 2015. Hubungan usia, pendidikan, paritas dengan sikap ibu hamil mengenal tanda-tanda bahaya kehamilan di Puskesmas Piyungan Bantul tahun 2015. Yogyakrta: Stikes Aisyiyah.

Kementerian Kesehatan RI. 2014. Riset Kesehatan Dasar, Riskesdas 2014. Kementerian Kesehatan.

Khoililurrohman. 2003. Hubungan Antara Kepercayaan Terhadap Mitos Kehamilan Dengan Perilaku Kehati-Hatian Menjelang Persalinan. Psikologi UGM Yogyakarta.

Manuaba. 2010. Ilmu kebidanan, Penyakit Kandungan dan KB untuk Bidan. Jakarta: Arcana.

Meutia. F, Swasno. 1998. Kehamilan, kelahiran, perawatan ibu dan bayi dalam aspek budaya indpnesia. Jakarta: UI.

Nirwana A. B. 2011. Kapita Selekta Kehamilan. Yogyakarta: Huna Medika. 
Tri Suhandoyo, dkk: Gambaran Persepsi Ibu Hamil Tentang Mitos Kehamilan

Notoatmodjo, S. 2012. Metodologi Penelitian Kesehatan. Jakarta: Rineka Cipta.

Notoatmodjo. 2012. Promosi Kesehatan dan Perilaku Kesehatan. Jakarta: Rineka Cipta.

Nursalam. 2013. Konsep dan Metode Peneleitian Ilmu Keperawatan, Pedoman Skripsi, Tesis dan Intrument Penelitian. Jakarta : Salemba Medika.

Walgito, B. 2010. Pengantar Psikologis Umum. Yogyakarta: Andi Offset.

Wahyudi, HK. 2010. Doa Mendampakan Momongan. Bandung: Mizan Pustaka

Riyanto, A. \& Budiman. 2013. Kapita selekta kuesioner pengetahuan dan sikap dalam penelitian kesehatan. Jakarta : Salemba Medika. 